\title{
Impact of deployment of "Stork Network" in hospitalizations in the Neonatal Intensive Care Unit
}

\author{
Impacto da implantação da Rede Cegonha nas hospitalizações em Unidade de Terapia \\ Intensiva Neonatal
}

Sandra Mara Aparecida dos Santos de Andrade ${ }^{1}$, Cristiana Aparecida Soares Manzotti ${ }^{1}$, José Alípio Garcia Gouvêa ${ }^{1}$, Cristiane Faccio Gomes ${ }^{2}$, Marcelo Picinin Bernuci ${ }^{1}$, Angélica Capellari Menezes Cassiano ${ }^{1}$

Objective: to assess the impact of the deployment of "Stork Network" (Rede Cegonha) in hospitalizations in the Neonatal Intensive Care Unit. Methods: a retrospective cross-sectional study with 283 medical records of newborns hospitalized in neonatal intensive care unit before and after the implementation of Stork Network, correlating data from pregnant women with the babies' conditions. Results: after the implementation of Stork Network, the percentage of pregnant women who performed six or more visits to the hospital increased $6.5 \%$ and the diagnosis of hypertensive disorders of pregnancy reduced $10.8 \%$. It was also noted reduction of one week in the mean gestational age of babies and $14.4 \%$ reduction in the percentage of babies weighing $\geq 2500$ grams. The number of deaths during hospitalization increased from $2.4 \%$ to $14.5 \%$. Conclusion: the goal of performing screening and monitoring of risk pregnancies was reached, however, the reduction of neonatal mortality rate is still challenging.

Descriptors: Infant Death; Infant, Premature; Intensive Care Units, Neonatal.

Objetivo: avaliar o impacto da implantação da rede cegonha nas hospitalizações em Unidade de Terapia Intensiva Neonatal. Métodos: estudo retrospectivo e transversal, com 283 prontuários de recém-nascidos hospitalizados em unidade de terapia intensiva neonatal antes e após a implantação da Rede Cegonha, correlacionando dados da gestante às condições dos bebês. Resultados: após a implantação da Rede Cegonha, a porcentagem de gestantes que realizaram seis ou mais consultas aumentou 6,5\% e diagnóstico de doença hipertensiva específica da gestação reduziu 10,8\%. Notou-se também redução de uma semana na idade gestacional média dos bebês bem como redução de $14,4 \%$ na porcentagem de bebês com peso $\geq 2500$ gramas. 0 número de óbitos durante a hospitalização passou de $2,4 \%$ para $14,5 \%$. Conclusão: a meta de realizar triagem e monitoramento das gestações de risco foi atingida, entretanto, a redução da taxa de mortalidade neonatal ainda é desafio.

Descritores: Morte do Lactente; Prematuro; Unidades de Terapia Intensiva Neonatal.

\footnotetext{
${ }^{1}$ Centro Universitário Cesumar. Maringá, PR, Brazil.

${ }^{2}$ Universidade Norte do Paraná. Londrina, PR, Brazil.

Corresponding author: Sandra Mara Aparecida dos Santos de Andrade

Rua Rio Poa, 358 - Jardim Dourados, CEP: 87040-670. Maringá, PR, Brazil. E-mail: s.mara.santos2013@bol.com.br
} 


\section{Introduction}

In the year 2000 it was agreed among the 191 countries of the United Nations, including Brazil, an action plan for the progress of health and overall wellbeing, known as "Millennium Development Goals"(1). Among the many objectives of this plan, there is the reduction of child mortality, particularly the decline in $2 / 3$ of the mortality rate among children under five years old ${ }^{(2)}$.

To achieve this objective, the care provided during prenatal, childbirth and the first weeks of life of the newborn is critical because recent data from the United Nations Inter-agency Group for Child Mortality Estimates ${ }^{(3)}$ showed that in 2013, 45.0\% of deaths of children under five years old occurred in the neonatal period, of which $73.0 \%$ were in the first week and $36.0 \%$ in the first 24 hours. Estimate from United Nations Children's Fund in 2013 revealed that $35.0 \%$ of neonatal deaths in the world occurred due to premature labor and $24.0 \%$ due to complications during childbirth, suggesting that the actions directed to the newborn care are still in need of improvement. The neonatal mortality rate in 2013 in Brazil was 13.7 deaths per thousand live births ${ }^{(4)}$, which is below the minimum recommended by the World Health Organization: less than 10 deaths per thousand live births.

In order to reduce neonatal mortality, various actions were instituted. One was the creation of a special program of care for mother and baby, called "Stork Network," which proposes to improve access and quality of prenatal care and during birth in the public health system in Brazil(5). Besides standard care to pregnancy, childbirth and the postpartum period, with the provision of prenatal care, laboratory tests and transportation, this program also focuses on actions involved to reduce neonatal mortality, ensuring beds and linking the pregnant woman to a particular maternity or specialized public hospital, and to offer the Stork Mobile Emergency Care Service to newborns requiring emergency transport with ambulances equipped with incubators and neonatal ventilators $^{(6)}$.

The government of Paraná, a Brazilian state linked to this national program, created the Paranaense Mother Network, a program that proposes the organization of maternal and child care in the actions of prenatal and postpartum period and the monitoring of the growth and development of children, especially in their first year of life. In Maringa city, the "Maringaense Mother" program has maintained the same goals of Paranaense Mother Network and includes the micro-region of Northern Parana, with 30 municipalities. It has the city of Maringa as care center, and the linked hospitals are the Maringa University Hospital and the Santa Casa de Maringa Hospital, which have high complexity Neonatal Intensive Care Units for specialized care to newborns in the region ${ }^{(7-8)}$.

Data from medical records of hospital admissions in Neonatal Care Units may facilitate the characterization of the profile of both mothers and newborns hospitalized and support studies on the effectiveness of implementation of the program in the care of high-risk pregnant women.

This study aimed to evaluate the impact of the deployment of "Stork Network" in hospitalizations in the Neonatal Intensive Care Unit.

\section{Methods}

This is a retrospective and cross-sectional study with 283 medical records of newborns hospitalized in Neonatal Intensive Care Units before and after the implementation of "Stork Network", correlating data from pregnant women with the babies' conditions.

It is a regional reference for high-risk pregnancies and has 11 beds in the Neonatal Intensive Care Unit, of which eight are exclusive for care of cases arising from the Unified Health System.

Secondary data were obtained from medical records filed in paper or scanned in Tasy system of neonates born and in the Neonatal Intensive 
Care Unit exclusively by the Unified Health System. The information on the profile of the newborn and the pregnant woman and the care provided were obtained from medical records of newborns who met the inclusion criteria for the study.

It was held a comparative study of all records included in the study in two distinct periods: before and after the implementation of "Stork Network" in Maringá. 1) Pre-implementation (October 2010 to March 2011) ( $\mathrm{n}=83)$ and 2) Post-implementation (April 2011 to March 2013) ( $\mathrm{n}=200)$.

The records of multiple newborns or with congenital malformations and chromosomal syndromes were excluded, as they refer to babies with characteristics that could cause bias in the interpretation of the data. The variables included maternal characteristics (age, parity, previous abortions history) prenatal conditions (number of visits, clinical conditions) and fetal conditions (gestational age, birth weight, Apgar score in the fifth minute of life and mortality). All variables were stratified into two groups: pre- and post-implementation of the "Stork Network". It was estimated the gross odds ratio (OR) for each factor by univariate logistic regression analysis, testing its significance level of $5.0 \%$. The results of the Chi-square test association and the significance level was also set at $5 \%$ in order to measure the strength of association between the variables. Statistical analyzes were performed using the Statistical Analysis System, version 9.3 and R (R Development Core Team).

The study complied with the formal requirements contained in the national and international standards of regulatory research involving human subjects.

\section{Results}

The evaluated medical records totaled 83 in the first period (pre-implementation) and 200 in the second period (post-implementation). Table 1 presents data on pregnancy characteristics of newborns admitted to the neonatal intensive care unit in the pre- and post-implementation periods of the "Stork Network". After the implementation, the percentage of mothers under the age of 18 years increased by $8.0 \%$ and there was increase of $9.0 \%$ of previous abortions. There was also an increase of $6.5 \%$ of pregnant women who attended six or more prenatal visits. As for pregnancy complications, there was an increase of $12.5 \%$ of urinary tract infection after the implementation of the program and reduction of $10.8 \%$ of hypertensive disorders of pregnancy. Before the implementation of "Stork Network", 47.0\% of pregnancies went beyond 35 weeks and more than one-third of babies were born with more than 2500 grams, whereas after the implementation, $53.0 \%$ of pregnancies took place between 30 to 35 weeks and a fifth of babies were born with more than 2500 grams.

Table 1 - Pregnancy characteristics of newborn infants admitted to the Neonatal Intensive Care Unit in the pre- and post-implementation periods of the "Stork Network"

\begin{tabular}{|c|c|c|}
\hline Factors & $\begin{array}{l}\text { Pre-imple- } \\
\text { mentation } \\
\mathbf{n}(\%)\end{array}$ & $\begin{array}{c}\text { Post-imple- } \\
\text { mentation } \\
\mathrm{n}(\%)\end{array}$ \\
\hline \multicolumn{3}{|c|}{ Gestational age (weeks) } \\
\hline $24 \mid-30$ & $11(13.2)$ & $29(14.5)$ \\
\hline $30 \mid-35$ & $33(39.7)$ & $106(53.0)$ \\
\hline$\geq 35$ & $39(46.9)$ & $65(32.5)$ \\
\hline \multicolumn{3}{|c|}{ Birthweight (kg) } \\
\hline$<1$ & $4(4.8)$ & $17(8.5)$ \\
\hline $1 \mid-1.5$ & $9(10.8)$ & $34(17.0)$ \\
\hline $1.5 \mid-2.5$ & $41(49.4)$ & $108(54.0)$ \\
\hline$\geq 2.5$ & $29(34.9)$ & $41(20.5)$ \\
\hline \multicolumn{3}{|c|}{ Mother's age (years) } \\
\hline $15 \mid-18$ & $5(6.0)$ & $28(14.0)$ \\
\hline $18 \mid-35$ & $59(71.0)$ & $151(75.5)$ \\
\hline$\geq 35$ & $19(22.8)$ & $21(10.5)$ \\
\hline \multicolumn{3}{|c|}{ Child's gender } \\
\hline Male & $46(55.4)$ & $102(51.0)$ \\
\hline Female & $37(44.5)$ & $98(49.0)$ \\
\hline \multicolumn{3}{|c|}{ Number of consultations } \\
\hline$<6$ & $44(53.0)$ & $93(46.5)$ \\
\hline$\geq 6$ & $39(46.9)$ & $107(53.5)$ \\
\hline \multicolumn{3}{|c|}{ Urinary tract infection } \\
\hline No & $39(46.9)$ & $69(34.5)$ \\
\hline Yes & $44(53.0)$ & $131(65.5)$ \\
\hline \multicolumn{3}{|c|}{ Hypertensive disease specific of preg- } \\
\hline \multicolumn{3}{|c|}{ nancy } \\
\hline No & $28(33.7)$ & $89(44.5)$ \\
\hline Yes & $55(66.2)$ & $111(55.5)$ \\
\hline \multicolumn{3}{|c|}{ Number of previous pregnancies } \\
\hline$<4$ & $79(95.1)$ & $189(94.5)$ \\
\hline$\geq 4$ & $4(4.8)$ & $11(5.5)$ \\
\hline \multicolumn{3}{|c|}{ Previous miscarriages } \\
\hline No & $79(95.1)$ & $173(86.5)$ \\
\hline Yes & $4(4.8)$ & $27(13.5)$ \\
\hline Total & $83(100.0)$ & $200(100.0)$ \\
\hline
\end{tabular}


Table 2 presents results of the univariate analysis of gestational age due to the factors studied before and after the implementation of "Stork Mother Network". Pregnant women who attended less than six prenatal consultations are less likely $(\mathrm{OR}=0.62)$ that the duration of the pregnancy exceeds 35 weeks than those who had visited six times or more, although at the level of $5 \%$ of significance, the difference between the odds is not significant $(\mathrm{p}=0.09)$. Other factors studied showed no significant differences between their levels in the odds ratio estimated in relation to gestational age.
Table 3 presents data on the characterization of obstetric complications in newborns occurred before and after implementation of the "Stork Mother Network". In both periods, the discomfort and respiratory failure were the main neonatal complications found. The number of cases with premature rupture of membranes and administration of antibiotics to infants was similar in both periods. Therefore, records of premature labor decreased from $77.4 \%$ to $27.5 \%$ after implementation of the program. Conversely, deaths during hospitalization in the neonatal intensive care unit increased from $2.4 \%$ to $14.5 \%$.

Table 2 - Univariate analysis of gestational age due to factors under study and results of the chi-square test of association in the post-implementation period of "Stork Mother Network"

\begin{tabular}{|c|c|c|c|c|c|c|c|}
\hline \multirow{2}{*}{ Factors } & \multicolumn{3}{|c|}{ Gestational age } & \multirow{2}{*}{ Gross OR } & \multirow{2}{*}{ CI 95\% } & \multirow{2}{*}{ p value } & \multirow{2}{*}{ p value * } \\
\hline & $24 \mid-30$ & $30 \mid-35$ & $35|-| 41$ & & & & \\
\hline Mother's age (years) & & & & & & & 0,2 \\
\hline $15 \mid-18$ & 7 & 11 & 10 & 0.8 & $0.3-1.7$ & 0.5 & \\
\hline $18 \mid-35$ & 20 & 81 & 50 & 1.0 & - & - & \\
\hline$\geq 35$ & 2 & 14 & 5 & 0.8 & $0.3-1.9$ & 0.6 & \\
\hline Peso (kg) & & & & & & & $<0.01$ \\
\hline$<1.5$ & 26 & 22 & 3 & 0.01 & $0.01-0.04$ & $<0.01$ & \\
\hline $1.5 \mid-2.5$ & 3 & 70 & 35 & 0.26 & $0.1-0.5$ & $<0.01$ & \\
\hline$\geq 2.5$ & - & 14 & 27 & 1.00 & - & - & \\
\hline Gender & & & & & & & 0.28 \\
\hline Male & 11 & 58 & 33 & 1.2 & $0.7-2.0$ & 0.51 & \\
\hline Female & 18 & 48 & 32 & 1.0 & - & - & \\
\hline Number of consultations & & & & & & & 0.17 \\
\hline$<6$ & 15 & 54 & 24 & 0.6 & $0.3-1.07$ & 0.09 & \\
\hline$\geq 6$ & 14 & 52 & 41 & 1.0 & - & - & \\
\hline Urinary tract infection & & & & & & & 0.98 \\
\hline No & 10 & 36 & 23 & 1.00 & - & - & \\
\hline Yes & 19 & 70 & 42 & 0.9 & $0.5-1.6$ & 0.8 & \\
\hline Hypertensive disease specific of pregnancy & & & & & & & 0.46 \\
\hline No & 15 & 43 & 31 & 1.0 & - & - & \\
\hline Yes & 14 & 63 & 34 & 0.9 & $0.5-1.6$ & 0.9 & \\
\hline Number of previous pregnancies & & & & & & & 0.27 \\
\hline$<4$ & 28 & 102 & 59 & 1.0 & - & - & \\
\hline$\geq 4$ & 1 & 4 & 6 & 2.5 & $0.7-8.2$ & 0.1 & \\
\hline Previous miscarriages & & & & & & & 0.86 \\
\hline No & 26 & 91 & 56 & 1.0 & - & - & \\
\hline Yes & 3 & 15 & 9 & 1.1 & $0.5-2.4$ & 0.7 & \\
\hline
\end{tabular}


Table 3 - Frequency distribution of obstetric complications in newborns in both periods

\begin{tabular}{lcccc}
\hline & \multicolumn{2}{c}{ Pre-implementation } & Post-implementation \\
\cline { 2 - 5 } $\begin{array}{l}\text { Obstetric complications } \\
\text { in newborns }\end{array}$ & $\mathbf{n}(\%)$ & $\mathbf{n}(\%)$ & $\mathbf{n}(\%)$ & $\mathbf{n}(\%)$ \\
\hline $\begin{array}{l}\text { Preterm birth } \\
\text { Mechanical pulmonary }\end{array}$ & $219(77.4)$ & $64(22.5)$ & $77.8(27.5)$ & $205.1(72.5)$ \\
respiration & $161.7(57.1)$ & $122(42.8)$ & $151.0(53.3)$ & $131.9(46.6)$ \\
Respiratory complications & $257.3(83.8)$ & $45.6(12.9)$ & $258.2(91.2)$ & $24.7(8.7)$ \\
Use of surfactant & $10.0(35.4)$ & $272.9(64.5)$ & $110.4(39.0)$ & $172.5(60.9)$ \\
Use of antibiotic & $26.4(93.5)$ & $26.1(6.4)$ & $25.0(88.4)$ & $24.7(11.5)$ \\
Deaths & $6.7(2.4)$ & $276.2(97.6)$ & $4.1(14.5)$ & $3.8(85.5)$ \\
Vaginal delivery & $72.5(25.6)$ & $210.4(74.3)$ & $5.9(21.0)$ & $5.6(78.9)$ \\
\hline
\end{tabular}

\section{Discussion}

Some maternal characteristics are associated with higher risk of complications for mothers and infants. These complications are closely influenced by age, parity, and gestational interval of women. The risk of a pregnant woman present any complications is minimal between 18 and 30 years old and their second to fourth pregnancy. It increases gradually (2 to 3 times), in mothers under the age of 18 years or above 30 years old. Hemorrhage, toxemia, dystocia are increased at the first pregnancy, and from the 5th onwards. Additionally, women need from 2 to 3 years between births to fully recover from pregnancy and prepare for another. The smaller the interval, the greater the risk of maternal death, which falls on the child (severe anemia, prematurity and other complications of pregnancy and childbirth) ${ }^{(6)}$. These factors are intrinsic to the woman and, although impossible to change during follow-up, are the target of screening and classification for referral to risk prenatal care.

The conclusion is that in the postimplementation period of the program there was the percentage increase of pregnant women aged under 18 and with previous abortions. The number of previous pregnancies above or equal to four remained similar between the two periods. It is noticed also an increase in the number of prenatal consultations and diagnosis of clinical complications (urinary tract infection) found during the post-implementation period of the "Stork Network Program". Infections should be diagnosed, as they have important role in the evolution of pregnancy due to the potential to lead to prematurity by several mechanisms, including premature rupture of membranes ${ }^{(9)}$. Such information suggests better quality of prenatal care provided in basic health units, possibly with more effective risk screening, increased supply of professionals, consultations and diagnostic tests.

The findings of this study show that the main cause of hospitalization in the Neonatal Intensive Care Unit in the two periods is prematurity and its respiratory complications. The etiology of preterm birth, excluding premature rupture of membranes, twin pregnancy, uterine malformations and cervical isthmus-incompetence, remains elusive. Some preterm births are caused with the specific purpose to rid the product of intrauterine adverse conditions. These conditions are related to intrauterine infection, hypertensive disease specific of the pregnancy, among others ${ }^{(10)}$. Among the factors known to be related to prematurity, premature rupture of membranes remained similar in both periods. There was reduction of the premature labor rate in the postimplementation period. One possible explanation for this reduction can be the increased diagnosis and treatment of urinary tract infections during pregnancy and increase the number of prenatal visits.

The Hypertensive Disease Specific of Pregnancy is the most important clinical entity of the current obstetrics, a view that is based in the relatively high incidence, in ignorance of its true etiology and in the still present high maternal and fetal mortality, reflecting the innocuousness of therapeutic resour$\operatorname{ces}^{(11)}$. According to data found, there was decrease in cases where pregnant women develop Hypertensive Disease Specific of Pregnancy after the implementation of the program, but they still remain high. 
Neonatal mortality and morbidity are higher in preterm neonates; furthermore, the economic burden associated with these births is significant, as the early delivery demands higher level and complexity care. Also, general immaturity can lead to dysfunction in any organ or body system and the infant may suffer impairment or complications throughout their development ${ }^{(12)}$. In the postimplementation period the mean gestational age was lower, and the birthweight and Apgar score in the fifth minute of life were also lower. Obviously, it is expected an unfavorable prognosis in the evolution of these neonates. There was an increase in mortality, which increased from $2.4 \%$ to $14.5 \%$ of deaths during hospitalization in the Neonatal Intensive Care Unit in the post-implementation period. One can compare the results with other Neonatal Intensive Care Unit service where there were $8.2 \%$ of deaths in hospitalized newborns in the Neonatal Intensive Care Unit, of which specifically $29.3 \%$ were of infants weighing less than $1,500 \mathrm{~g}$, including children with malformations ${ }^{(13)}$.

On the other hand, other authors have indicated that improving prenatal care (quality of care), staff training, as well as adequate care delivery and reduced number of caesareans can contribute to the reduction of neonatal mortality ${ }^{(14)}$. In another study of relationship between gestational risk and type of delivery with maternal and neonatal consequences, the findings revealed that, although cesarean section has not directly influenced maternal findings, there was an increase of chances of neonatal complications ${ }^{(15)}$.

Normal deliveries occurred in $25.6 \%$ of births in the pre-implementation period and $21.0 \%$ after implementation of the program. Whereas infants evaluated in the study were at high risk, the high number of caesarean sections is justified, for this type of delivery is considered a protective factor in fetal prognosis. This is contrary to the expected in populations of low-risk infants, in which the high number of caesarean sections is unjustifiable and increases maternal and fetal morbidity ${ }^{(13,16-17)}$.
Although a higher cesarean section rate in highrisk pregnancies is expected, this study found $74.3 \%$ of cesarean sections before the implementation of the program and $78.9 \%$ after the implementation of the program, which is above the recommended by the Ministry of Health, which is up $40.0 \%$ for risk pregnancies and $25.0 \%$ for low-risk pregnancies. The authors noticed that high cesarean section rates reveal the abuse of this technology, performance of unnecessary procedures, reduced quality of care and poor training and professional qualification ${ }^{(18-19)}$. The Technical Note No. 31 of the National Council of Health Secretaries ${ }^{(17,20)}$ presents clear indications to the high-risk pregnancy hospital reference services, with indications for reducing cesarean section, episiotomy and use of oxytocin during labor.

As for the impact of the implementation of "Stork Network" in prematurity and birthweight, it must be observed that, prior to its implementation, births occurred also in the municipalities of origin of the mother and, when necessary, mother and/or child was referred to another service upon availability of places, or were not referred by lack of adequate transportation or failure to diagnose the risk diseases during the prenatal, delivery or postpartum care.

Currently, high-risk babies are born in the reference hospital, since it has technological resources (operating room, cardiotocography, ultrasound, Neonatal Intensive Care Unit, respirators, general equipment) and technical resources (obstetrician, neonatologist pediatrician, anesthesiologist, nurses, speech therapists, physical therapists, psychologists, nursing technicians and others in the multidisciplinary team) to provide better conditions for the birth and care in the first hours of life. Consequently, gestational age and birthweight after the implementation of "Stork Network" were lower. Authors believe that these findings are, contrary to what one might imagine at first sight, synonymous with improvement in service. Thus, the "Stork Network Program" has succeeded in early identification and referral of risk pregnant women in the public health network. 


\section{Conclusion}

The implementation of the "Stork Network" has been effective in ensuring better diagnosis of disorders during prenatal care, number of consultations and referrals for high-risk prenatal care, as well as the increase in births of high-risk infants in a reference hospital. At the expense of these actions, prematurity remains a key factor for hospitalization in Neonatal Intensive Care Unit.

But the present study had difficulties due to lack of data in the medical records regarding mothers and babies, improper storage of the records and even the nonexistence of records with that name, although such storage must be kept for five years in minimum.

\section{Collaborations}

Andrade SMAS, Manzotti CAS, Gouvêa JAG, Gomes CF, Bernuci MP and Cassiano ACM contributed to the design, analysis, data interpretation, article writing and final approval of the version to be published.

\section{References}

1. United Nations Sustainable Development Summit. Cúpula sobre desenvolvimento sustentável, 25-27 de setembro, sede das NU. Nova York, EUA: United Nations Sustainable Development Summit; 2015.

2. Buss PM, Magalhães DP, Setti AFF, Gallo E, Franco Netto FA, Machado JMH, et al. Saúde na agenda de desenvolvimento pós-2015 das Nações Unidas. Cad Saúde Pública. 2014; 30(12):2555-70.

3. You D, Hug L, Ejdemyr S, Idele P, Hogan D, Mathers C, et al. Global, regional, and national levels and trends in under-5 mortality between 1990 and 2015, with scenario-based projections to 2030: a systematic analysis by the UN Inter-agency group for child mortality estimation. Lancet. 2015; 386(10010):2275-86.
4. United Nations Children's Fund (UNICEF). Committing to child survival: a promise renewed. Progress report 2014. New York: UNICEF; 2014.

5. Araújo JPA, Silva RMMDS, Collet N, Neves ET, Tos BRGDO, Viera CS. História da saúde da criança: conquistas, políticas e perspectivas. Rev Bras Enferm. 2014. 67(6):1000-7.

6. Gonçalves ITJP, Souza KV, Amaral MA, Oliveira ARS, Ferreira WFC, Gonçalves ITJP, et al. The embracement practice in prenatal care: limits, potentialities and contributions of nursing. Rev Rene. 2013; 14(3):620-9.

7. Prefeitura do Município de Maringá. Rede mãe Maringaense. Maringá: Prefeitura do Município de Maringá; 2013.

8. Governo do Estado do Paraná. Secretaria de Saúde. Linha Guia Mãe Paranaense. Curitiba: Secretaria de Saúde do Estado do Paraná; 2014.

9. Mariana PB, Wanderson LC, Andréia CG, Waldemar NA. Importance of prenatal genetic diagnosis. Rev Femina. 2012; 40(1):1-11.

10. Fernanda MM, Juliana MN, Maria CAS, Mirtz JARA, Sâmia MM, Lucília SG. A review of the clinical and demographic characteristics and perinatal outcomes in women with gestational hypertension syndrome. Rev Eixo. 2013; 2(1):69-82.

11. Guerreiro DD, Borges WD, Nunes HHM, Silva SC, Maciel JP. Mortalidade materna relacionada à Doença Hipertensiva Específica da Gestação (DHEG) em uma maternidade no Pará. Rev Enferm UFSM. 2014; 4(4):825-34.

12. Ramos HAC, Cuman RKN. Fatores de risco para prematuridade: pesquisa documental. Esc Anna Nery. 2009; 13(2):297-304.

13. Granzotto JÁ, Fonseca SSD, Lindemann FL. Fatores relacionados com a mortalidade neonatal em uma Unidade de Terapia Intensiva neonatal na região Sul do Brasil. Rev AMRIGS. 2012; 56(1):57-62.

14. Soares ES, Menezes GMDS, Fatores associados à mortalidade neonatal precoce: análise de situação no nível local. Epidemiol Serv Saúde. 2010; 19(1):5-6. 
15. Reis ZSN, Lage EM, Aguiar RALP, Gaspar JS, Vitral GLN, Machado EG. Associação entre risco gestacional e tipo de parto com as repercussões maternas e neonatais. Rev Bras Ginecol Obstet. 2014; 36(2):65-71.

16. Silva AAM, Leite AJM, Lamy ZC, Moreira MEL, Gurgel RQ, Cunha AJLA, et al. Neonatal near miss in the Birth in Brazil survey. Cad Saúde Pública. 2014; 30(suppl):1-10.

17. Cassiano AMC, Carlucci EMDS, Gomes CF, Bennemann RM. Saúde materno-infantil no Brasil: evolução e programas desenvolvidos pelo Ministério da Saúde. Rev Serv Pública. 2014; 65(2):227-44.
18. Sanches NC, Mamede FV, Vivancos RBZ. The profile of women who have experienced cesarean section and obstetric care at a public maternity hospital in Ribeirao Preto. Rev Esc Enferm USP. 2012; 21(2):418-26.

19. Silva GF, Pelloso SM. Profile of pregnant women and their newborns attended at a hospital school of Parana Northwes. Rev Esc Enferm USP. 2009; 43(1):95-102.

20. Leal MC, Pereira APE, Domingues RMSM, Theme Filha MM, Dias MAB, Nakamura-Pereira $M$, et al. Obstetric interventions during labor and childbirth in Brazilian low-risk women. Cad Saúde Pública. 2014; 30(Suppl 1):17-32. 